\title{
Investigation of the relationship between idiopathic intracranial hypertension and superior semicircular canal dehiscence
}

\author{
Idiopatik intrakranial hipertansiyon ile superior semisirküler kanal dehissansı arasındaki \\ ilişkinin araştırılması
}

Defne Gürbüz, Melis Koşar Tunç, Semih Karaketir, Güler Berkiten, Onur Akan

Gönderilme tarihi:09.11.2021

Kabul tarihi:19.11.2021

\begin{abstract}
Purpose: The etiology of superior semicircular canal dehiscence (SSCD) is not yet clear; however, several theories implicate cumulative erosive changes. Here, using thin-section temporal bone CT images, we aimed to investigate the relationship between the bone roof thickness overlying the SSC and idiopathic intracranial hypertension $(\mathrm{IIH})$ which may cause repetitive microtrauma.

Materials and methods: Between January 2017-December 2019, temporal bone CT scans from 18 patients with a diagnosis of $\mathrm{IIH}$, and 21 age- and sex-matched controls were analyzed retrospectively. Multiplanar reformatted images (Pöschl and Stenver) were reconstructed from the scans and the roof thickness of the SSC bone was measured and SSCD was classified in 4 grades.

Results: A total of 78 thin-section temporal bone CT scans were evaluated. Although grade-II dehiscence was most frequent in both groups, grade-IV was only observed in both temporal bones of one patient in the IIH group. Grade-III and grade-IV dehiscence rates were significantly higher in the IIH group $(p=0.006)$. There was a significant difference between IIH and control groups in terms of SSC bone roof thickness $(p=0.03)$.

Conclusion: Increased CSF pressure in patients with IIH may cause chronic, progressive, and irreversible damage to the bone that covers the superior semicircular canal, and may play a role as a predisposing factor for SSCD.
\end{abstract}

Key words: Superior semicircular canal dehiscence, temporal bone CT, idiopathic intracranial hypertension.

Gurbuz D, Kosar Tunc M, Karaketir S, Berkiten G, Akan O. Investigation of the relationship between idiopathic intracranial hypertension and superior semicircular canal dehiscence. Pam Med J 2022;15:133-139.

Öz

Amaç: Superior semisirküler kanal dehissansının (SSKD) etyolojisi henüz net olarak bilinmemekle birlikte etyolojide kümülatif erozif değişikliklerin olabileceğine dair teoriler bulunmaktadır. Bu çalışmada ince kesit temporal kemik BT ile elde edilen görüntülerde SSK üzerindeki kemik çatı kalınlığının tekrarlayıcı mikrotravmalara sebebiyet verebilecek idiopatik intrakranial hipertansiyon ile ilişkisinin araştırılması amaçlanmıştır.

Gereç ve yöntem: Ocak 2017-Aralık 2019 tarihleri arasında idiopatik intrakranial hipertansiyon (iiH) tanısı ile takip edilen, ince kesit temporal kemik BT'si bulunan 18 hasta ve yaş-cinsiyet açısından eşleştirilmiş 21 sağlıklı gönüllü retrospektif çalışmamıza dahil edildi. Görüntüler üzerinden multiplanar reformat rekonstrüksiyon imajlar (Pöschl ve Stenver) elde edildi ve SSK üzerindeki kemik çatı kalınlığı ölçülerek SSKD 4 ayrı gruba sınıflandırıldı. Bulgular: Toplam 78 ince kesit temporal kemik BT değerlendirildi. Her iki grupta en sık grade 2 dehissans gözlenirken; grade 4 sadece IïH hasta grubunda bir hastanın her iki temporal kemiğinde izlendi. Grade 3 ve 4 dehissans oranı kontrol grubuyla karşılaştırıldığında IïH hasta grubunda anlamlı olarak yüksek saptandı $(p=0,006)$. İ̈H ve kontrol grubu arasında SSK kemik çatı kalınlığı açısından anlamlı fark görüldü $(p=0,03)$.

Sonuç: IïH hastalarında artmış beyin omurilik sıvı basıncı superior semisirküler kanal kemik çatısında kronik, ilerleyici ve geri dönüşümsüz hasara neden olabilir ve SSKD için predispozan bir faktör olarak rol oynayabilir.

Anahtar kelimeler: Superior semisirküler kanal dehissansı, temporal kemik BT, idiopatik intrakranial hipertansiyon.

Gürbüz D, Koşar Tunç M, Karaketir S, Berkiten G, Akan O. İdiopatik intrakranial hipertansiyon ile superior semisirküler kanal dehissansı arasındaki ilişkinin araştııılması. Pam Tıp Derg 2022;15:133-139.

Defne Gürbüz, M. D. (Specialist), University of Health Sciences, Prof. Dr. Cemil Taşçığlu City Hospital, Clinic of Radiology, Istanbul, Turkey, e-mail: defnegurbuz@yahoo.com (https://orcid.org/0000-0003-0280-1197) (Corresponding Author)

Melis Koşar Tunç, M. D. (Assistant), University of Health Sciences, Prof. Dr. Cemil Taşçıoğlu City Hospital, Clinic of Radiology, Istanbul, Turkey, e-mail: meliskosar@hotmail.com (https://orcid.org/0000-0001-6800-126X)

Semih Karaketir, M. D. (Specialist), Bulanik State Hospital, Clinic of Otorhinolaryngology, Mus, Turkey, e-mail: semihkaraketir@hotmail.com (https://orcid.org/0000-0002-6645-7105)

Güler Berkiten, M. D. (Ass. Prof.), University of Health Sciences Turkey, Prof. Dr. Cemil Taşçığlu City Hospital, Clinic of Otorhinolaryngology, Istanbul, Turkey, e-mail: gulerberkiten@gmail.com (https://orcid.org/0000-0002-1532-6113)

Onur Akan, M. D. (Specialist), University of Health Sciences Turkey, Prof. Dr. Cemil Taşçıoglu City Hospital, Clinic of Neurology, Istanbul, Turkey, e-mail: dronurakan@hotmail.com (https://orcid.org/0000-0001-8520-670X) 


\section{Introduction}

Superior semicircular canal dehiscence (SSCD) is a rare temporal bone pathology, characterized by the formation of a "third window" between the canal and the middle cranial fossa as a result of a defect in the bony roof overlying the superior semicircular canal (SSC). SSCD syndrome was first reported in 1998 by Minor et al. [1, 2]. It includes various audiovestibular symptoms such as vertigo, tinnitus, hearing loss, Tullio phenomenon (vertigo and nystagmus occurring with loud sounds), oscillopsia, autophonia, and hyperacusis that occur secondary to soundpressure changes as a result of the bone roof defect [3-5]. Although its etiology is not clearly known, there are theories suggesting that it occurs as a result of congenital, developmental, and genetic causes and cumulative erosive changes due to repetitive microtraumas such as increased cerebrospinal fluid (CSF) pressure [3-6]. It has been suggested that SSCD may occur due to the erosion of the bone overlying the superior semicircular canal in patients with idiopathic intracranial hypertension $(\mathrm{IIH})$ who have chronically high CSF pressures [4-6].

The aim of this study is to investigate the relationship between bone roof thickness overlying the superior semicircular canal and IIH using the images obtained with thin-section temporal bone computed tomography (CT) scanning.

\section{Materials and methods}

There were 23 patients followed up at the Neurology Clinic of our hospital with the diagnosis of IIH (with CSF opening pressure $\geq 25 \mathrm{~cm} \mathrm{H}_{2} \mathrm{O}$ in males, $\geq 20 \mathrm{~cm} \mathrm{H}_{2} \mathrm{O}$ in females) between January 2017-December 2019. Among these, 18 had a total of 36 thin-section temporal bone CT scans taken due to audiovestibular symptoms registered at the system and were included in the study. We also included a control group, comprising 42 temporal bone CT scans, from the same time period, of 21 age- and sexmatched patients complaining from different audiovestibular symptoms with no associated clinical findings or suspicion for $\mathrm{IIH}$. Patients under the age of 18 , patients with intracranial hypertension due to secondary causes, patients detected with high intracranial pressure due to lumbar puncture, and patients who were diagnosed with IIH but do not have temporal bone CT scanning images recorded in our system were excluded from the study.

The scans were evaluated by two radiologists, one with ten years of head and neck radiology and neuroradiology and the other with four years of general radiology experience. The evaluation of the roof thickness of the bone overlying the SSC and SSCD was made with consensus without prior knowledge on the clinical features of the patients.

In our study, high-resolution CT images obtained using Philips Ingenuity 128-slice CT scanning device with routine parameters (section thickness of $0.8 \mathrm{~mm}$, tube voltage of $120 \mathrm{kV}$, tube current of $280 \mathrm{mAs}$ ) were retrospectively analyzed. Multiplanar reformatted reconstruction images (Pöschl and Stenver) were obtained from axial scans (Figure 1). The roof thickness of the bone overlying the superior semicircular canal was measured from the thinnest point of the bone roof in the Pöschl plane, which allows the SSC to be seen as a complete ring and was graded according to the grading system defined by N. Klopp Dutote et al. [7]. According to this grading system, patients with bone roof thickness above 2.5 $\mathrm{mm}$ were defined as grade-I, while patients with roof thickness less than $2.5 \mathrm{~mm}$ were defined as grade-II. Grades -III and -IV were defined as pre-dehiscence and dehiscence, respectively, according to the presence of dehiscence in the semicircular canal in contact (Figure 2).

Statistical analyses were performed using the SPSS (Statistical Package for the Social Sciences) 22.0 statistical package software. The relationship between categorical data was evaluated using the chi-square test. The compliance of the data to normal distribution was determined using Kolmogorov Smirnov test. Student $\mathrm{t}$ test was used for normally distributed data for the comparison of the averages of two independent groups, while Mann-Whitney $U$ test was used for comparison of data not following normal distribution. For evaluating the relationships between continuous data, Pearson correlation test was used for data following normal distribution, while Spearman correlation test was used for data that do not conform to normal distribution. Statistical significance level was accepted as $p<0.05$. 

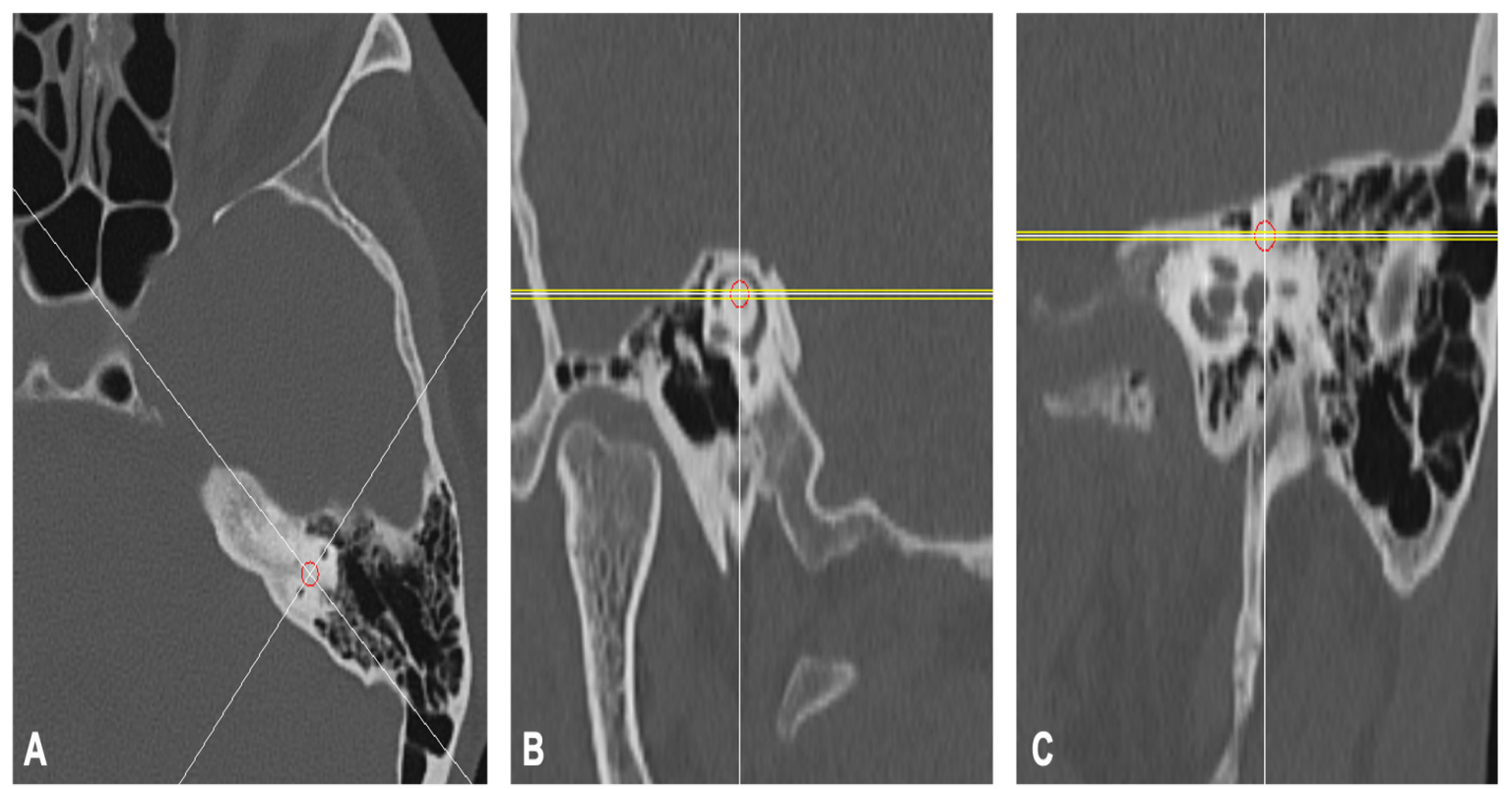

Figure 1. Reconstructions from the axial temporal bone CT (A), where superior semicircular canal appearing in forms of ascending limb, apex and descending limb as one complete ring in Pöschl's plane. Bone roof overlying the superior semicircular canal is intact. (B), Superior semicircular canal seen in Stenver's plane $(\mathrm{C})$

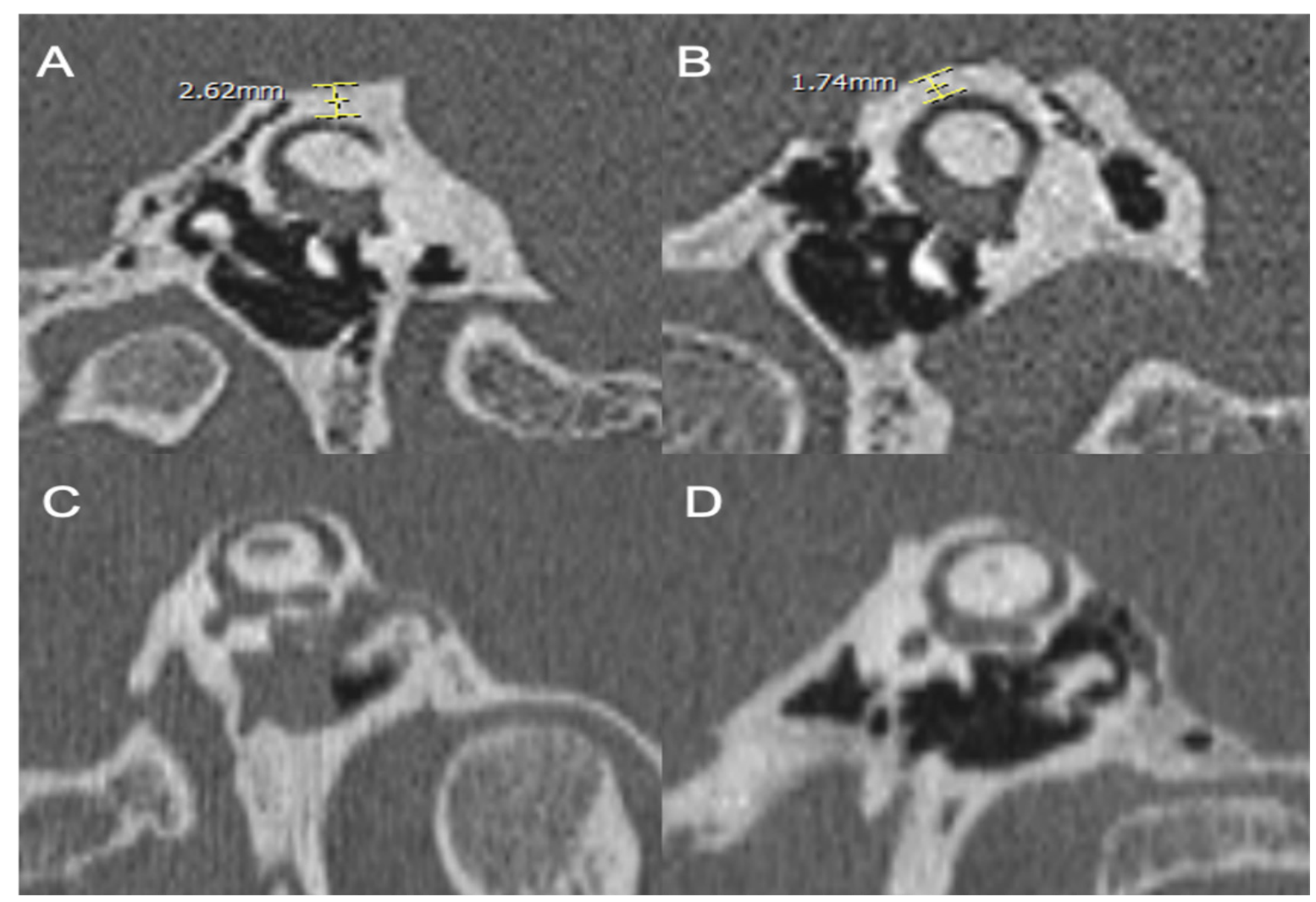

Figure 2. Measurement of bone roof thickness overlying the superior semicircular canal in Pöschl's plane and grading in terms of dehisssence. Grade I (A), Grade II (B), Grade III (C), Grade IV (D) SSCD 
Ethical approval was obtained for this retrospective study by University of Health Sciences, İstanbul, Turkey, Prof. Dr. Cemil Taşçıoğlu City Hospital, Local Ethics Committee.

\section{Results}

In our study, 78 thin-section temporal bone CT images from 18 patients in the $\mathrm{IIH}$ patient group and 21 patients in the control group (a total of 39 patients) were evaluated. The female/ male ratio was similar across the two groups: 15 female patients (83.3\%) in the IIH group and 16 female patients (76.2\%) in the control group. The two groups were also similar in terms of age distribution with a mean \pm standard deviation of
$40.5 \pm 12.27$ and $39.3 \pm 10.67$ years in the $\mathrm{IIH}$ and control groups, respectively.

Table 1 shows the distribution of patients in the IIH and control groups according to the grading system. Although grade-II was observed most frequently in both groups; grade-IV was only observed in both temporal bones of one patient in the IIH patient group.

SSC bone roof thickness was $2.55 \pm 0.05 \mathrm{~mm}$ in grade-I and $1.21 \pm 0.38 \mathrm{~mm}$ in grade-II in the IIH patient group. In the control group, SSC bone roof thickness was $2.55 \pm 0.04 \mathrm{~mm}$ in grade-I and $1.17 \pm 0.49 \mathrm{~mm}$ in grade-II. Compared with the control group, the number of grade-III and -IV

Table 1. Number (Frequency) of radiological SSCD grades in IIH and control groups

\begin{tabular}{llll}
\hline SSCD Grade & IIH & Control & Total \\
\hline Grade-I & $3(8.3 \%)$ & $6(14.3 \%)$ & $9(11.5 \%)$ \\
Grade-II & $20(55.6 \%)$ & $31(73.8 \%)$ & $51(65.4 \%)$ \\
Grade-III & $11(30.5 \%)$ & $5(11.9 \%)$ & $16(20.5 \%)$ \\
Grade-IV & $2(5.6 \%)$ & $0(0 \%)$ & $2(2.6 \%)$ \\
Total & 36 & 42 & 78 \\
\hline
\end{tabular}

patients were found to be significantly higher in the IIH patient group ( $p=0.006)$. In addition, all grades considered, there was a significant difference between SSC bone roof thickness of $\mathrm{IIH}$ and control groups ( $p=0.03$ ) (Figure 3). According to the examination performed in both groups, it was found that the bone roof defect was at the base of the middle cranial fossa in $14(18 \%)$ temporal bones, while the defect was observed to be at the level of superior petrous sinus groove in four four $(5 \%)$ temporal bones.

The average ( \pm standard deviation) of body-mass index (BMI) was $29.9( \pm 5.9)$ in the IIH patient group, while the mean $( \pm$ standard deviation) CSF opening pressure was 26.8 $( \pm 5.5) \mathrm{cm} \mathrm{H}_{2} \mathrm{O}$. There was no significant difference in body-mass indices and CSF opening pressure measurements between grade I-II (non-dehiscence) and grade III-IV (respectively, pre-dehiscence and dehiscence) groups in this patient group ( $p=0.08$ and $p=0.05$, respectively). Considering all IIH patients, it was observed that as the CSF opening pressure increases, the bone roof thickness decreases; however, no significant correlation was found between these two $(p=0.14)$.

\section{Discussion}

The underlying mechanism of SSCD development is highly controversial. Both congenital and acquired causes were implicated in etiological studies [8-10]. It is also suggested that the cumulative microtrauma created by $\mathrm{IIH}$ on the semicircular canal may play a role in etiopathogenesis. However, there is limited information on this subject in the literature.

In our study, a significant difference was found between the patients diagnosed with $\mathrm{IIH}$ and the control group in terms of SSC bone roof thickness $(p<0.05)$. Besides, the number of grade-III (pre-dehiscence) and -IV (dehiscence) patients was significantly higher among patients with $\mathrm{IIH}(p<0.05)$. Schutt et al. [11] reported that SSCD is more common in patients with obesity and obstructive sleep apnea, which are known to be associated with IIH. Although the patients included in the study by Schutt et al. [11] did not have a definite diagnosis of $\mathrm{IIH}$, the demonstration of this relationship in the patient profile of IIH supports the findings obtained in our study. In addition, the same study reported that SSCD was bilateral in 12 out of 31 cases $(38.7 \%)$ and it was suggested that an effect that 


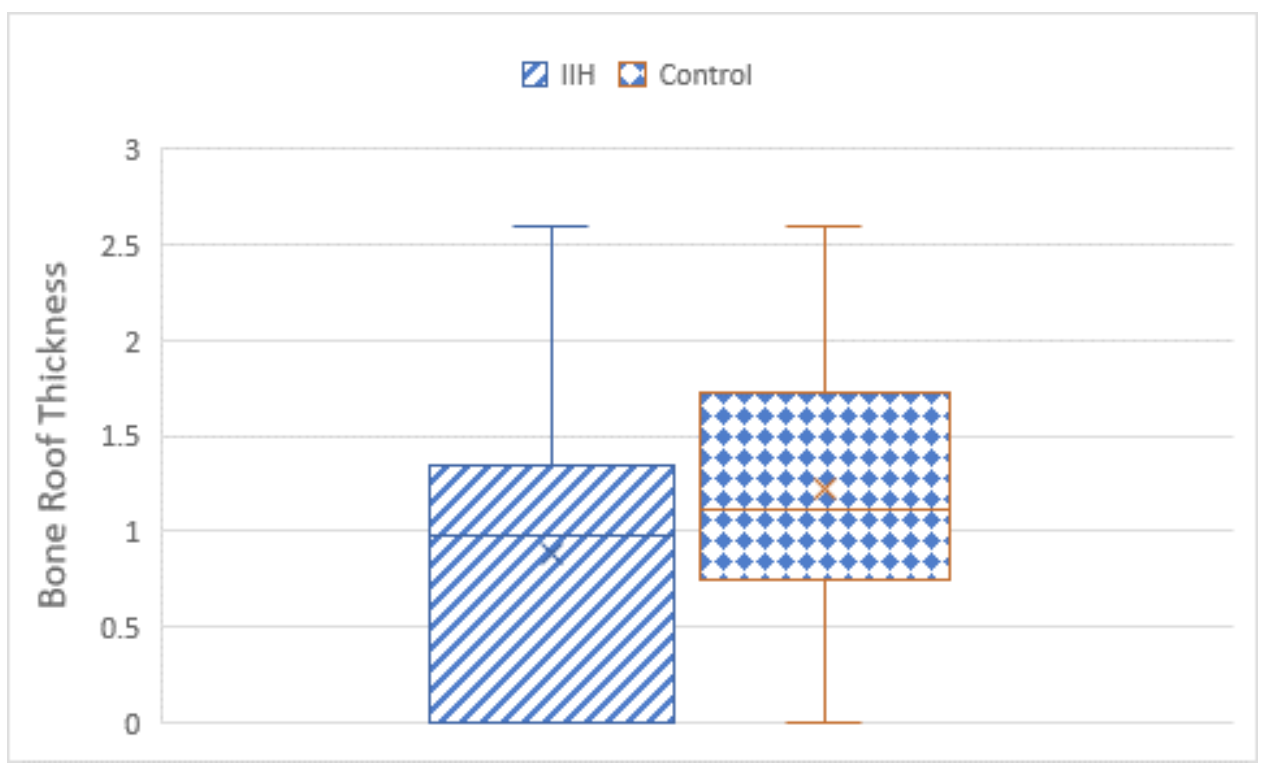

Figure 3. Comparison of bone roof thickness overlying the SSC in IIH and Control groups

would create erosion in both temporal bones, such as an increase in intracranial pressure, could play a role in the etiopathogenesis. In the study by Kuo et al. [12], 121 patients who had undergone a lumbar puncture procedure were evaluated and $\mathrm{IIH}$ was found in 24 cases. The remaining 97 patients constituted the control group and the relationship between SSCD and IIH was investigated in this cohort of 121 cases. The study reported no significant correlation between SSCD and IIH. However, in this study, only the presence/absence of SSCD was evaluated without any grading; therefore, the patients with pre-dehiscence were not included in the analysis. In addition, the control group was selected among patients with lumbar puncture indication, which did not reflect the healthy population. In our study, the control group consisted of patients who did not have any cranial pathology other than audiovestibular symptoms and they were not clinically considered to have $\mathrm{IIH}$ as a result of neuroophthalmic examination.

El Hadi et al. [13] detected concomitant semicircular canal dehiscence in 13 patients out of 23 cases (56\%) scheduled for surgical repair due to spontaneous tegmen defect. Moreover, in 12 of these 13 cases (92.3\%), SSC was found to be protruding into the middle cranial fossa, and the authors stated that as a result of this protrusion, the bony roof may be more exposed to the changes in intracranial pressure which may cause a predisposition to dehiscence and tegmen defect. Another study found the rate of accompanying tegmental defect to be significantly higher in cases with SSCD than in cases without SSCD [11]. These studies indicate that increased pulsatile CSF pressure may play a role as a common etiopathogenesis mechanism between the SSC bone roof and tegmental defect development. In our study, although CSF opening pressure increased as SSC bone thickness decreased in the IIH patient group, there was no significant correlation between the two conditions $(p=0.18)$. The reason may be due to our inability to compare this relationship between $\mathrm{IIH}$ and control patient groups due to the lack of CSF opening pressure measurements in the control group.

It is known that high BMI is an important parameter among the predisposing factors of IIH. In our study, no significant difference was found in terms of BMI and CSF opening pressure measurements between grade I-II (non-dehiscence) and grade III-IV (predehiscence and dehiscence, respectively) groups diagnosed with $\mathrm{IH}(p=0.08$ and $p=0.05$, respectively). Previous studies have shown a relief in IIH symptoms as a result of weight loss [14]. However, even though BMI reduction in patients diagnosed with $\mathrm{IIH}$ provides relief of symptoms, the changes in SSC bone roof thickness occur irreversibly. Therefore, SSC does not necessarily change in response to changes in weight, implying a lack of relationship between SSC bone roof thickness and BMI measured at any point in time. 
Our study has three major limitations. Firstly, we were not able to include the CSF opening pressure measurements for the control group in our analysis as it was not possible to perform lumbar puncture due to ethical considerations. Secondly, the data set did not include the BMI values for the control group, that only allowed us to retrospectively analyze bony roof thickness of SCC and SSCD grading. Last but not least, a larger sample with sufficiently many subjects in each SSCD grade would be recommended in future studies.

Increased CSF pressure in patients with $\mathrm{IIH}$ may cause chronic, progressive, and irreversible damage to the bone overlying the superior semicircular canal, and may play a role as a predisposing factor for SSCD.

Conflict of interest: No conflict of interest was declared by the authors.

\section{References}

1. Minor LB, Solomon D, Zinreich JS, Zee DS. Sound- and/ or pressure-induced vertigo due to bone dehiscence of the superior semicircular canal. Arch Otolaryngol Head Neck Surg 1998;124:249-258. https://doi.org/10.1001/ archotol.124.3.249

2. Minor LB. Clinical manifestations of superior semicircular canal dehiscence. The Laryngoscope 2005;115:1717-1727. https://doi.org/10.1097/01. mlg.0000178324.55729.b7

3. Ceylan N, Bayraktaroglu S, Alper $\mathrm{H}$, et al. CT imaging of superior semicircular canal dehiscence: added value of reformatted images. Acta Oto Laryngologica 2010;130:996-1001. https://doi. org/10.3109/00016481003602108

4. Friedland DR, Michel MA. Cranial thickness in superior canal dehiscence syndrome implications for canal resurfacing surgery. Otol Neuroto 2006;27:346354. https://doi.org/10.1097/00129492-20060400000010

5. Hirvonen TP, Carey JP, Liang CJ, Minor LB. Superior canal dehiscence: mechanisms of pressure sensitivity in a chinchilla model. Arch Otolaryngol Head Neck Surg 2001;127:1331-1336. https://doi.org/10.1001/ archotol.127.11.1331

6. Stimmer H, Hamann KF, Zeiter S, Naumann A, Rummeny EJ. Semicircular canal dehiscence in HR multislice computed tomography: distribution, frequency, and clinical relevance. Eur Arch Oto Rhino Laryngol 2012;269:475-480. https://doi.org/10.1007/ s00405-011-1688-6
7. Klopp Dutote N, Kolski C, Biet A, Strunski V, Page C. A radiologic and anatomic study of the superior semicircular canal. Eur Ann Otorhinolaryngol Head Neck Dis 2016;133:91-94. https://doi.org/10.1016/j. anorl.2015.11.001

8. Cisneros, Al, Whyte J, Martínez C, et al. Radiological patterns of the bony roof of the superior semicircular canal. Surg Radiol Anat 2013;35:61-65. https://doi. org/10.1007/s00276-012-1019-7

9. Nadgir RN, Ozonoff A, Devaiah AK, Halderman AA, Sakai O. Superior semicircular canal dehiscence: congenital or acquired condition? AJNR 2011;32:947949. https://doi.org/10.3174/ajnr.A2437

10. Zhou G, Ohlms L, Liberman J, Amin M. Superior semicircular canal dehiscence in a young child: implication of developmental defect. International Journal of Pediatric Otorhinolaryngology 2007;71:19251928. https://doi.org/10.1016/j.ijporl.2007.08.009

11. Schutt CA, Neubauer P, Samy RN, et al. The correlation between obesity, obstructive sleep apnea, and superior semicircular canal dehiscence: a new explanation for an increasingly common problem. Otol Neurotol 2015;36:551-554. https://doi.org/10.1097/ MAO.0000000000000555

12. Kuo P, Bagwell KA, Mongelluzzo G, et al. Semicircular canal dehiscence among idiopathic intracranial hypertension patients. Laryngoscope 2018;128:11961199. https://doi.org/10.1002/lary.26795

13. El Hadi T, Sorrentino T, Calmels MN, Fraysse B, Deguine O, Marx M. Spontaneous tegmen defect and semicircular canal dehiscence: same etiopathogenic entity? Otol Neurotol 2012;33:591-595. https://doi. org/10.1097/MAO.0b013e31824bae10

14. Subramaniam S, Fletcher WA. Obesity and weight loss in Idiopathic Intracranial hypertension: a narrative review. J Neuro Ophthalmology 2017;37:197-205. https://doi.org/10.1097/WNO.0000000000000448

Ethics committee approval: Ethical approval was obtained for this retrospective study in line with the decision taken in the session dated 27 May 2020, and decision number is 48670771-514.10 of University of Health Sciences, İstanbul, Turkey, Prof. Dr. Cemil Taşçıoğlu City Hospital, Local Ethics Committee.

This article was presented as an oral presentation at the 41th National Radiology Congress held in Antalya on October 28, 2020. 


\section{Contribution of the authors}

Study conception and design: D.G., M.K.T. Acquisition of data: D.G., M.K.T., S.K., G.B., O.A.. Analysis and interpretation of data: D.G., M.K.T. Drafting of manuscript: D.G., M.K.T., S.K., G.B., O.A. Critical revision: D.G. All the authors approved the final version to be published; all authors agreed to all aspects of the work. 